(c) 2022, The Authors. Published by Elsevier Inc. and Fass Inc. on behalf of the American Dairy Science Association ${ }^{\circledR}$. This is an open access article under the CC BY license (http://creativecommons.org/licenses/by/4.0/).

\title{
Negative producer price differentials in Federal Milk Marketing Orders: Explanations, implications, and policy options
}

\author{
Marin Bozic ${ }^{1}\left(0\right.$ and Christopher A. Wolf ${ }^{2 *}$ (1) \\ ${ }^{1}$ Department of Applied Economics, University of Minnesota-Twin Cities, St. Paul 55108 \\ ${ }^{2}$ Charles H. Dyson School of Applied Economics and Management, Cornell University, Ithaca, NY 14853
}

\begin{abstract}
In Federal Milk Marketing Orders (FMMO), which use multiple component pricing schemas, farmers are paid for delivered quantity of butterfat, protein, and other solids, plus a producer price differential (PPD). The PPD captures the difference between the total handler obligations to the pool and the total component value of milk. In 2020, record negative PPD caused widespread frustration among dairy farmers. The primary objective of this research was to provide a comprehensive analysis of factors that affect PPD and to quantify their relative importance. We examined FMMO data from the past $10 \mathrm{yr}$ including prices, utilizations, and tests. By decomposing the PPD, we were able to isolate the drivers of negative values. We found that long-term trends in usage, most importantly declining beverage milk and rising component tests, including both butterfat and protein, have substantially reduced PPD over the past decade. Class I milk pricing reform of 2018 exacerbated negative PPD in 2020, but we found that the PPD would have been negative even without that reform. The greatest contributor to recent negative PPD was the spread between cheese and milk powder prices, caused by shifts in demand due to the COVID-19 pandemic and USDA intervention cheese purchases. A range of policy modifications proposed to address negative PPD was evaluated.
\end{abstract}

Key words: dairy policy, federal milk marketing orders, milk price, producer price differential

\section{INTRODUCTION}

Federal Milk Marketing Orders (FMMO) are one of the primary dairy policies in the United States. Over the 2015-2019 period, $64.3 \%$ of milk produced in the United States was pooled on FMMOs. In those orders, where most of the milk is used in manufactured dairy

Received April 26, 2021

Accepted September 6, 2021.

*Corresponding author: cwolf@cornell.edu products, dairy farmers are paid based on butterfat, protein, and other solids content of their milk, and a producer price differential (PPD). The PPD reconciles the difference between component valuation of milk, and available revenue derived from the market value of dairy products in which milk was used. Historically, a substantial share of milk was used in beverage milk products. Per FMMO rules, beverage milk is generally priced at a premium relative to milk used for manufactured dairy products. This normally suffices to make the average milk value higher than the component milk value, resulting in a positive PPD. The PPD is thus often interpreted by dairy producers as a financial measure of benefit of FMMO regulations.

In 2020, record low negative PPD caused consternation and frustration among dairy farmers and ignited widespread mistrust in the milk pricing system. These PPD were not just abnormal in magnitude, they were unpredictable and greatly contributed to farm milk price volatility. Volatility in milk prices can adversely affect dairy farm profitability. Past research has demonstrated that increased basis risk - volatile and unpredictable differences between the farm milk price and the class III milk price - is a primary reason that dairy farmers do not use available risk management tools (Wolf, 2012). Dairy farmers considering milk price risk management must examine price and margin behavior over time (Bozic et al., 2012). Milk utilization and other FMMO considerations are key to predicting prices for risk management (De Vries and Feleke, 2008). The excessive volatility in PPD contributes directly to farm milk price uncertainty and blunts both the motivation and effectiveness of farm milk price risk management.

Several factors were blamed for volatile, negative PPD, including recent changes to beverage milk pricing rules, reduced beverage milk consumption, and dairy processors leaving the FMMO during the COVID-19 pandemic. In 2021, many in the US dairy sector called for dairy policy reforms to address negative PPD. This research examines the causes of negative PPD. We carefully detail how PPD are calculated and develop a framework to identify and quantify the relative im- 
portance of 6 factors driving PPD: utilization of milk by dairy product type, rise of butterfat and protein content of milk, variability in dairy product prices, advanced pricing of beverage milk, beverage milk pricing formula reforms enacted in the 2018 Farm Bill, and depooling. The framework we develop is used to evaluate the potential of a range of policy modifications to alleviate negative PPD.

Paggi and Nicholson (2013) provide a recent summary of literature on FMMO, revealing that negative PPD were not a focus of earlier research efforts. In the rare circumstances when they were observed, Jesse and Cropp (2008) explained, negative PPD were a shortterm consequence of sudden rally in manufacturing milk price, after beverage milk price for the month had already been determined. Stephenson and Novakovic (2020) explored how the COVID-19 pandemic affected milk prices and suggested that PPD on farm milk checks may reflect milk price deductions unrelated to FMMO regulations. Instead these deductions were largely due to additional costs processors incurred because of disturbance to supply chains in the pandemic economy.

This research makes 3 primary contributions. First, we develop a set of models based on formal FMMO accounting rules to quantify effects of factors contributing to PPD. This allows us to estimate long-term negative trends in PPD due to the shrinking share of raw milk usage in production of beverage milk products, as well as the effect of USDA intervention programs introduced during the pandemic. Second, this work is the first to our knowledge to derive conditions under which negative PPD can persist for many months. Finally, the modeling framework is used to evaluate several policy reform proposals.

\section{MATERIALS AND METHODS}

\section{Overview of Federal Milk Marketing Orders}

The FMMO are a collective bargaining institution created nearly a century ago in geographically defined regional fluid milk demand areas (Congressional Research Service, 2017). The FMMO regulate minimum prices paid for raw milk by all distributors of fluid milk products and promote uniform participation by all area dairy producers in market sales value of fluid milk (Nourse, 1962). At their peak number in 1962, there were 83 FMMO (Swantz, 1962). Currently, there are 11 FMMO, with California being the most recent area to join in November 2018. In areas regulated under FMMO, milk processing plants converting raw milk to beverage milk products must participate in the marketing order. For all other milk processing plants, participation is voluntary, and incentivized by the prospect of sharing in revenue generated through sales of beverage milk products. The accounting procedures used to operationalize these objectives and incentives are classified pricing and revenue pooling. Processors contribute to the revenue pool based on the class of dairy products manufactured, and class-based milk prices derived from freely established wholesale market prices of basic dairy commodities. Total milk handler obligation to the pool is referred to as the classified value of milk. Order-wide pooled revenue is then distributed to dairy producers based on the attributes of their milk, such as butterfat test and SCC, irrespective of the class of dairy products where their milk was used.

Classified Pricing. Under classified pricing, dairy manufacturers (referred to as handlers) participating in the order have the obligation to the pool based on the type of the dairy products where the milk is used. Milk is placed into 4 utilization classes based on end use. Class I includes all milk (butterfat and skim milk) used in fluid beverage products, including whole, lowfat, and skim milk, eggnog, and buttermilk. Class II includes milk used to produce semi-solid products such as cottage cheese, milkshakes, sour cream, yogurt, and custards. Class III milk includes milk used to produce spreadable and hard cheeses and whey byproducts. Class IV milk includes milk used to produce butter, condensed milk, and any milk product in dried form, primarily nonfat dry milk. Minimum prices for each class of milk are derived from national surveys of wholesale dairy product prices. The products included are cheese, butter, nonfat dry milk, and dry whey. These product prices are surveyed weekly by the USDA, which collects value and sales volume at the wholesale level.

Revenue Pooling. Under revenue pooling, a dairy farmer shipping milk to a privately owned handler who participates in the FMMO is guaranteed a minimum price based on the component levels and dairy plant location. Minimum farm milk price is not dependent directly on the revenue their handler generated through sales of dairy products, as such revenue is pooled with revenue from other dairy processors participating in the FMMO.

In those FMMO where most of the milk is used in manufactured dairy products, dairy farmers are paid based on the component content of their milk. This milk pricing approach is called multiple component pricing (MCP). Seven orders use the MCP approach: Northeast (FMMO \#1), Mideast (FMMO \#33), Upper Midwest (FMMO \#30), Central (FMMO \#32), Southwest (FMMO \#126), Pacific Northwest (FMMO \#124), and California (FMMO \#51). ${ }^{1}$ The other 4 FMMOs-Appalachian (\#5), Arizona (\#131), Florida (\#6), and Southeast (\#7) - use skim-fat pricing. Skimfat pricing orders calculate the producer value of milk 
as the weighted average or uniform value of fat and skim. Prices are set based on the fat content in milk and everything else is categorized as skim. The result being all parts of skim milk are valued identically. In the period from 2015 to $2019,86.7 \%$ of the total national pooled milk amount was pooled on marketing orders, which used MCP.

Under MCP the producer value of milk is determined monthly based on component levels including fat, protein, and other solids (lactose and whey proteins). Butterfat price is derived from market price for bulk butter. Protein price is derived from the market price for commodity cheddar cheese, and other solids price is derived from dry whey. Total component value of milk in the pool is determined by multiplying butterfat, protein and other solids total pooled pounds by their respective component prices.

The difference between total pooled revenue and the funds allocated to dairy producers based on component value of milk, is denoted as the PPD. When revenue remains in the pool after allocating the component value of milk, PPD dollars are divided among dairy producers based on the pounds of milk marketed, and location adjustments based on the location of the dairy processing plant where milk was used. When the component value of milk exceeds the total pooled revenue, then deductions must be applied to each producer, following the same procedures used to distribute remaining dollars when PPD is positive. To understand what may cause the total pooled revenue to exceed, or fall short of component value of milk, we first consider the accounting protocols determining handler obligations to the pool.

\section{Producer Price Differential Calculation}

Component prices in FMMO are determined by taking the wholesale product price less a make allowance multiplied by yield. Make allowances are credits for the cost of processing, whereas the yield is the amount of the commodity that can be produced using $1 \mathrm{lb}$. (1 lb. $=0.453592 \mathrm{~kg}$ ) of the component. Make allowances have been updated only once in the past 2 decades - in 2009. Minimum regulated prices for milk components are calculated as follows.

The butterfat component price is derived from the price of butter as

$$
p_{B F}=\left(p_{B}-0.1715\right) \times 1.211,
$$

where $p_{B}$ is the monthly average Grade AA butter survey price reported by the USDA, $\$ 0.1715$ is the butter make allowance, and 1.211 is the butter manufacturing yield. The class II butterfat price is

$$
p_{B F, I I}=p_{B F}+0.007 \text {. }
$$

The protein price is based on the price of cheese and butter. Protein component price is derived from the protein value in cheese adjusted for any difference between the value of butterfat in butter and cheese:

$$
\begin{aligned}
p_{P R}= & \left(p_{C}-0.2003\right) \times 1.383+\left[\left(p_{C}-0.2003\right)\right. \\
& \left.\times 1.572-p_{B F} \times 0.9\right] \times 1.17
\end{aligned}
$$

where $p_{C}$ is the monthly average Cheddar cheese survey price reported by the USDA, $\$ 0.2003$ /hundredweight (cwt) is the cheese make allowance, 1.383 is the cheese yield attributable to protein, 1.572 is the cheese yield attributable to butterfat, 0.9 is the butterfat retention rate, and 1.17 is the butterfat to protein ratio in cheese (USDA Agricultural Marketing Service, 2019).

The other solids price is derived from the price of dry whey:

$$
p_{O S}=\left(p_{D W}-0.1991\right) \times 1.03,
$$

where $p_{D W}$ is the monthly average dry whey survey price reported by the USDA, $\$ 0.1991 /$ cwt is the dry whey make allowance, and 1.03 is the dry whey manufacturing yield.

The nonfat solids price is based on the price of nonfat dry milk:

$$
p_{N F S}=\left(p_{N F D M}-0.1678\right) \times 0.99,
$$

where $p_{N F D M}$ is the monthly average nonfat dry milk survey price reported by the USDA, $\$ 0.1678 /$ cwt is the nonfat dry milk make allowance, and 0.99 is the nonfat dry milk manufacturing yield. These component prices are used to determine the fat and skim values for each class of milk.

To facilitate retail pricing, regulated prices for class I and class II products are set before the start of the month. Weighted average prices from the first 2 wk of each month are used to calculate the "advanced prices" for the following month used to price class I (fluid) and II products. Advanced prices are announced by the 23rd of the month for the following month. Advanced butterfat, protein, other solids, and nonfat solids prices are denoted respectively as $p_{B F, A}, p_{P R, A}, p_{O S, A}, p_{N F S, A}$. Advanced component prices are calculated using the same formulas as monthly average component prices, 
but instead of monthly average dairy commodity prices, the calculation uses advanced dairy commodity prices. These advanced component prices are used in advanced class I, III, and IV skim milk and class II nonfat solids price.

Advanced class III skim milk pricing factor:

$$
p_{S, I I I, A}=3.1 \times p_{P R, A}+5.9 \times p_{O S, A} .
$$

Advanced class IV skim milk pricing factor:

$$
p_{S, I V, A}=9 \times p_{N F S, A} .
$$

Class II nonfat solids price:

$$
p_{N F S, I, A}=p_{N F S, A}+0.70 / 9 .
$$

And base class I skim milk price:

$$
p_{S, I, A}=\left(p_{S, I I I, A}+p_{S, I V, A}\right) / 2+0.74 .
$$

Rather than the average in Equation [9], from January 2000, through April 2019, the base class I skim milk price was calculated as the higher of the advanced class III skim milk pricing factor and advanced class IV skim milk pricing factor:

$$
p_{S, I, A, 2000-2018}=\max \left(p_{S, I I I, A}, p_{S, I V, A}\right) .
$$

Total pooled weight of milk and cream in pounds is denoted as $W_{M}$ and is equal to the sum of total pooled weight of butterfat, $W_{B F}$, and total pooled weight of skim milk, $W_{S}$. Total weight of skim milk used in class IV is denoted as $W_{S, I V}$, and similar notation is used for other classes. Skim milk usage percentage in each class is defined as the ratio of the weight of skim milk utilized in that class and the total weight of pooled skim milk. For example, skim milk utilization rate in class IV is $U_{S, I V}=W_{S, I V} / W_{S}$.

Total pooled weights of butterfat, protein and other solids components are denoted, respectively, as $W_{B F}$, $W_{P R}$, and $W_{O S}$. When protein and other solids are combined, they are referred to as nonfat solids, $W_{N F S}=$ $W_{P R}+W_{O S}$. Pool average protein component test is $T_{P R}=W_{P R} / W_{M}$. Pool average other solids component test is calculated as $T_{O S}=W_{O S} / W_{M}$. Pool average nonfat solids component test is calculated as $T_{N F S}=W_{N F S} /$ $W_{M}$. Pool average butterfat component test is $T_{B F}=$ $W_{B F} / W_{M}$. This can be rewritten as $T_{B F}=1-W_{S} / W_{M}$. Reorganizing, we get $W_{M} / W_{S}=1 /\left(1-T_{B F}\right)$. Now average protein component test per unit of skim milk can be expressed as $T_{P R, S}=T_{P R} /\left(1-T_{B F}\right)$. Similarly, $T_{O S, S}$ $=T_{O S} /\left(1-T_{B F}\right)$ and $T_{N F S, S}=T_{N F S} /\left(1-T_{B F}\right)$.

\section{Handler Value of Milk}

Each handler reports to the pool total pounds of received skim milk, butterfat, protein, skim solids other than protein (other solids), as well as utilization of milk and milk solids by class. The classified value of milk in a FMMO each month is equal to the sum of obligations to the pool across all pooled handlers. Handler class I skim milk value is

$$
H_{I, S}=\left(p_{S, I, A}+p_{L, I}\right) \times U_{S, I} \times W_{M} / 100 \times\left(1-T_{B F}\right),
$$

where $p_{L, I}$ is the class I differential at the principal pricing point of the order, in $\$ /$ cwt.

Handler class I butterfat value is

$$
H_{I, B F}=\left(p_{B F, A}+p_{L, I} / 100\right) \times U_{B F, I} \times W_{M} \times T_{B F},[12]
$$

and total handler class I value is

$$
H_{I}=H_{I, S}+H_{I, B F}+L_{H} \times W_{M, I} / 100,
$$

where $L_{H}$ is the per hundredweight weighted average location adjustment to handlers, based on the class I differential zone where pooled plants are located.

Similarly, class II nonfat solids value is

$$
H_{I I, N F S}=p_{N F S, I I, A} \times U_{S, I I} \times T_{N F S} \times W_{M},
$$

The class II butterfat value is calculated as

$$
H_{I I, B F}=p_{B F, I I} \times U_{B F, I I} \times W_{M} \times T_{B F},
$$

and the total handler class II value is

$$
H_{I I}=H_{I I, N F S}+H_{I I, B F} .
$$

Class III protein value is

$$
H_{I I I, P R}=p_{P R} \times U_{S, I I I} \times T_{P R} \times W_{M},
$$

and the class III other solids value is

$$
H_{I I I, O S}=p_{O S} \times U_{S, I I I} \times T_{O S} \times W_{M} .
$$

Class III butterfat value is

$$
H_{I I I, B F}=p_{B F} \times U_{B F, I I I} \times W_{M} \times T_{B F},
$$

and total handler class III value is

$$
H_{I I I}=H_{I I I, P R}+H_{I I I, O S}+H_{I I I, B F} .
$$


Finally, class IV nonfat solids value is

$$
H_{I V, N F S}=p_{N F S} \times U_{S, I V} \times T_{N F S} \times W_{M},
$$

the class IV butterfat value is

$$
H_{I V, B F}=p_{B F} \times U_{B F, I V} \times W_{M} \times T_{B F},
$$

and the class IV value is

$$
H_{I V}=H_{I V, N F S}+H_{I V, B F} .
$$

Total classified value of milk, the sum of obligations to the pool across all pooled handlers, is expressed as

$$
H=H_{I}+H_{I I}+H_{I I I}+H_{I V}
$$

Total producer component value of milk, denoted $C$ is the sum of the product of butterfat pounds and butterfat price, the product of protein pounds and protein price, and the product of other solids pounds and other solids price. Total producer component value of milk is expressed as

$$
C=p_{B F} \times W_{B F}+p_{P R} \times W_{P R}+p_{O S} \times W_{O S} .
$$

The total producer price differential (TPPD) for each FMMO and month is the difference between total classified value of milk and total component value of milk, less location adjustment to producers, $L_{P} \times W_{M} / 100$ :

$$
T P P D=H-C-L_{P} \times W_{M} / 100
$$

Producer price differential per hundredweight of pooled milk is, therefore,

$$
P P D=\frac{T P P D}{W_{M} / 100} .
$$

\section{Factors Contributing to Negative PPD}

Factors that increase handler value of milk $H$ relative to producer component value $C$ have a positive effect on the PPD. Likewise, factors which decrease the handler value of milk relative to producer component valuation have a negative effect on producer price differential. We group the factors affecting PPD in 6 categories:

(1) Changes in utilization rates due to structural changes in dairy products production within the marketing order area: $U_{S, I}, U_{B F . I}, \ldots$

(2) Changes in component tests: $T_{B F}, T_{P R}, T_{O S}$.

(3) Changes in announced dairy product prices: $p_{B}$, $p_{C}, p_{D W}, p_{N F D M}$.

(4) Changes in advanced dairy product prices: $p_{B, A}$, $p_{C, A}, p_{D W, A}, p_{N F D M, A}$.

(5) Changes in class I skim milk pricing regimen; that is, from the "higher-of" regimen represented by Equation [10] to "average-of" regimen expressed in Equation [9].

(6) Changes in utilization rates $\left(U_{S, I}, U_{B F, I}, \ldots\right)$ due to "depooling," (i.e., handlers utilizing milk in class II, III or IV dairy products deciding to not pool that milk in the marketing order for one or more months).

\begin{tabular}{|c|c|c|c|c|c|}
\hline Step & Utilization rates & $\begin{array}{l}\text { Component } \\
\text { tests }\end{array}$ & $\begin{array}{l}\text { Announced } \\
\text { prices }\end{array}$ & $\begin{array}{l}\text { Advanced } \\
\text { prices }\end{array}$ & $\begin{array}{l}\text { Class I } \\
\text { pricing } \\
\text { formula }^{1}\end{array}$ \\
\hline 1. Trends in utilization rates & $\begin{array}{l}\text { Linear trend and } \\
\text { seasonal model }\end{array}$ & $\begin{array}{l}\text { Constant, } 2010 \\
\text { level }\end{array}$ & $\begin{array}{l}\text { Constant, } 2010- \\
2019 \text { average }\end{array}$ & $\begin{array}{l}\text { Equal to } \\
\text { announced } \\
\text { prices }\end{array}$ & $\begin{array}{l}\text { Higher-of } \\
\text { regimen }\end{array}$ \\
\hline $\begin{array}{l}\text { 2. Structural changes in } \\
\text { component tests }\end{array}$ & $\begin{array}{l}\text { Linear trend and } \\
\text { seasonal model }\end{array}$ & Actual & $\begin{array}{l}\text { Constant, } 2010- \\
2019 \text { average }\end{array}$ & $\begin{array}{l}\text { Equal to } \\
\text { announced } \\
\text { prices }\end{array}$ & $\begin{array}{l}\text { Higher-of } \\
\text { regimen }\end{array}$ \\
\hline 4. Impact of advanced pricing & $\begin{array}{l}\text { Linear trend and } \\
\text { seasonal model }\end{array}$ & Actual & Actual & Actual & $\begin{array}{l}\text { Higher-of } \\
\text { regimen }\end{array}$ \\
\hline $\begin{array}{l}\text { 5. Impact of } 2019 \text { class I pricing } \\
\text { reform }\end{array}$ & $\begin{array}{l}\text { Linear trend and } \\
\text { seasonal model }\end{array}$ & Actual & Actual & Actual & Actual \\
\hline 6. Depooling and structural changes & Actual & Actual & Actual & Actual & Actual \\
\hline
\end{tabular}

To isolate and quantify the importance of these 6 factors, we built a series of counterfactual models that progressively relax restrictions imposed on each category. These models are summarized in the Table 1 and explained in detail below.

Table 1. Factors affecting producer price differentials

${ }^{1}$ The class I pricing formula was changed from using the higher of classes III or IV to the average of those 2 classes plus $\$ 0.74 /$ hundredweight in 2018. 
Step 1: Change in Utilization Rates Due to Structural Changes. The long-term trend in FMMO is declining fluid milk utilization (class I). The percentage of producer milk used as class I declined from $65.5 \%$ in 1947 to $28.0 \%$ in 2019 (USDA Agricultural Marketing Service, 2020). Total pooled class I skim milk pounds across 6 federal orders analyzed declined from 2.69 billion pounds in January 2010 to 2.34 billion pounds in January 2021, a $13.3 \%$ reduction. This occurred both because beverage consumption declined over time but also because of increasing consumption of cheese (class III), yogurt (class II), and butter (class IV), as well as increasing exports of cheese and milk and whey powders. From Equation [27], the effect on $\mathrm{PPD}$ is given by

$$
\begin{aligned}
& \frac{\partial T P P D}{\partial W_{S, I}}=\left(p_{S, I, A}+p_{L, I}\right) / 100+L_{H} / 100 \\
& -p_{P R} T_{P R}\left(1-T_{B F}\right)-p_{O S} T_{O S}\left(1-T_{B F}\right)-L_{P} / 100 .
\end{aligned}
$$

Under the "higher-of" class I milk pricing regimen represented by Equation [10], assuming that advanced prices are equal to announced prices, and that per hundredweight location adjustment to handlers is equal to per hundredweight location adjustment to producers the effect is

$$
\begin{aligned}
& \frac{\partial T P P D}{\partial W_{S, I}}=\max \left(3.1 \times p_{P R}+5.9 \times p_{O S}, 9 \times p_{N F S}\right) / 100 \\
& +p_{L, I} / 100-p_{P R} T_{P R, S}-p_{O S} T_{O S, S} .
\end{aligned}
$$

Assuming further that $3.1 \times p_{P R}+5.9 \times p_{O S}>9 \times$ $p_{N F S}$, the effect becomes

$\frac{\partial P P D}{\partial W_{S, I}}=$
$\frac{p_{L, I} / 100-\left(T_{P R, S}-3.1 / 100\right) p_{P R}-\left(T_{O S, S}-5.9 / 100\right) p_{O S}-P P D / 100}{W_{M} / 100}$.

The expression in [30] is positive under all reasonable price and component test values. Therefore, the decline in class I sales is expected to reduce the PPD. To quantify the effect of declining fluid milk product sales on PPDs, we start by estimating utilization rates based on trend and seasonal factors:

$$
U_{t}=\beta_{1}+\beta_{2} N_{t}+\beta_{3} \sin \left(\frac{m_{t}}{12} \times 2 \pi\right)+\beta_{4}\left(\frac{m_{t}}{12} \times 2 \pi\right)+e_{t},
$$

where $N_{t}$ is the trend variable, with $N_{t}=1$ for January 2010 and $m_{t}$ is the calendar month index (1-12) for period $t$. For each federal order, we estimated the trend in utilization rates separately for skim milk and butterfat for each class.

To isolate the effect of changes in utilization rates on PPDs, we kept all factors other than utilization rates constant. Therefore, the Step 1 model has the following assumptions and restrictions:

(1) Utilization rates are set equal to those predicted by trend/seasonal models described in Equation [31]. Time-limited depooling is not allowed. The only source of changes to utilization rates are structural changes in dairy production and consumption.

(2) Component tests for each month are held constant at the levels observed in each respective 2010 calendar month, as summarized in Table 2.

(3) Announced dairy product and milk component prices are held constant at the average levels observed over January 2010 through December 2019, as summarized in Table 3.

(4) Advanced prices are set equal to the announced prices held constant at average 2010 to 2019 values.

(5) Base class I skim prices are calculated assuming they are priced using the higher of advanced class III skim milk pricing factor and advanced class IV skim milk pricing factor:

$$
p_{S, I, A}=\max \left(p_{S, I I I, A}, p_{S, I V, A}\right) .
$$

This was the official pricing method used by USDA from January 2000 through April 2019.

(6) Class I location differentials and location adjustments to producers are set at per hundredweight levels predicted by trend or seasonal models described in Equation [31].

Step 2: Change in Component Tests. The MCP rewards producers for the total amount of milkfat and protein produced (Bailey et al., 2005). In response, dairy farm managers have selected genetics and nutrition programs to increase component tests over time as the result of economic incentives. From Equation 27 , the effect of increase in the protein test on PPD is given by

$$
\begin{aligned}
& \frac{\partial T P P D}{\partial T_{P R}}=p_{N F S, A} \times U_{S, I I} \times W_{M}+p_{P R} \times U_{S, I I I} \times W_{M}+p_{N F S} \\
& \times U_{S, I V} \times W_{M}-p_{P R} \times W_{M} .
\end{aligned}
$$


Table 2. Average milk component tests ${ }^{1}$

\begin{tabular}{|c|c|c|c|c|c|c|}
\hline \multirow[b]{2}{*}{$\begin{array}{l}\text { Federal milk marketing } \\
\text { order (FO) }\end{array}$} & \multicolumn{3}{|c|}{2010} & \multicolumn{3}{|c|}{2020} \\
\hline & Butterfat \% & Protein $\%$ & $\begin{array}{l}\text { Other } \\
\text { solids \% }\end{array}$ & Butterfat $\%$ & Protein \% & $\begin{array}{c}\text { Other } \\
\text { solids \% }\end{array}$ \\
\hline FO \#1 - Northeast & 3.70 & 3.05 & 5.72 & 3.92 & 3.11 & 5.77 \\
\hline FO \#30 - Upper Midwest & 3.68 & 3.03 & 5.76 & 3.96 & 3.14 & 5.77 \\
\hline FO \#32 - Central & 3.60 & 3.07 & 5.74 & 3.92 & 3.20 & 5.79 \\
\hline FO \#33 - Mideast & 3.66 & 3.05 & 5.71 & 3.88 & 3.16 & 5.78 \\
\hline FO \#124 - Pacific Northwest & 3.73 & 3.14 & 5.71 & 4.07 & 3.25 & 5.77 \\
\hline FO \#126 - Southwest & 3.60 & 3.07 & 5.76 & 4.07 & 3.28 & 5.78 \\
\hline
\end{tabular}

${ }^{1}$ Data source: USDA-AMS, Federal Milk Marketing Order Statistics (https://www.ams.usda.gov/resources/marketing-order-statistics).

Assuming further that advanced prices are equal to announced prices, and that $p_{P R}>p_{N F S}$ :

$$
\begin{aligned}
& \frac{\partial P P D}{\partial T_{P R}}=\left(p_{N F S} \times U_{S, I I}+p_{P R} \times U_{S, I I I}+p_{N F S} \times U_{S, I V}-p_{P R}\right) \times 100 \\
& <0 .
\end{aligned}
$$

Increases in protein test reduce TPPD. The reduction is higher in FMMO where more milk is used in class I. Because the value of class I skim milk depends only on pounds of skim milk used, and not protein test, increasing the protein test does not increase the handler obligation to the pool for class I skim milk. The negative effect on PPD will also be more pronounced the wider the spread between protein price and nonfat solids price. All protein is paid to producers based on protein price, derived from cheese prices. However, only protein used in class III milk results in increased sales of dairy products where increased solids increase handler obligations to the pool proportional to the increase in component value of milk. When used in the production of nonfat dry milk powder, skim solids typically do not create as much value as when used in the production of cheese and whey. Handler obligations to the pool are increased by $p_{N F S}$ but component value of milk is increased by $p_{P R}$. The difference between the increase in component value of milk and handler obligations to the pool reduces the PPD. From the pool's perspective, the marginal cost (component value of milk) exceeds the marginal revenue (handlers obligations to the pool). The way that pool accounting is operationalized amounts to a transfer of money from low component herds to high component herds, a transfer that promotes cattle breeding selection and nutrition based on component tests.

Step 3: Variability in Announced Milk Component Prices. Under FMMO, skim solids are paid for based on their value in cheese and whey, but only a fraction of skim solids are used in cheese and whey. Skim solids are also used in nonfat dry milk powder, in yogurts and fluid milk. When there is a positive spread between market value of skim solids in cheese and whey compared with nonfat dry milk powder, then FMMO pay for components beyond the value they create in the market, and the deficit is manifested as a lower PPD. The extreme illustration of the spread between value of skim solids in cheese and whey compared with nonfat dry milk powder was provided by the COVID-19 pandemic. Due to extensive reduction in away-fromhome eating occasions, dairy prices collapsed in April 2020. The government intervened through the Farmers to Families Food Box program, which increased domestic disappearance of American-style cheese and fluid

Table 3. Dairy product and milk component prices summary statistics ${ }^{1}$

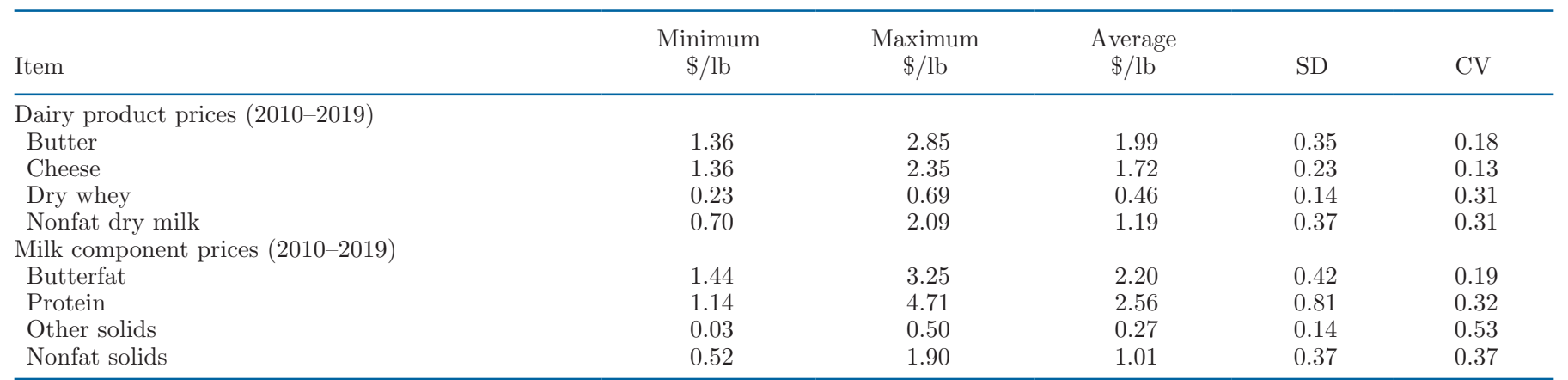

${ }^{1}$ Data source: USDA-AMS, Federal Milk Marketing Order Statistics (https://www.ams.usda.gov/resources/marketing-order-statistics). 
milk and resulted in record-high cheese prices as supply chain struggled to adjust to a shift in demand between cheese types (USDA, 2020). The onset of the Farmers to Families Food Box program coincided with record negative PPD.

From Equation [27], the impact on PPD from the increase in the protein price, holding other milk component prices constant and assuming that class III skim price is the class I mover in Equation [10], is given by

$$
\begin{aligned}
& \frac{\partial T P P D}{\partial p_{P R}}=\left[3.1 / 100 \times\left(1-T_{B F}\right)-T_{P R}\right] \times U_{S, I} \times W_{M}[35] \\
& -U_{S, I I} \times T_{P R} \times W_{M}-U_{S, I V} \times T_{P R} \times W_{M} .
\end{aligned}
$$

For all reasonable values for $T_{P R}$, this expression has a negative sign. In contrast, higher butter prices increase PPDs. If advanced prices are equal to announced monthly prices, then the direct impact on PPD from the increase in the butterfat price is zero. The effect of an increase in the butter price, holding other commodity prices constant, is therefore entirely indirect, through the reduction of the protein price.

Step 4: Advanced Prices. Advanced prices temper the immediate effect of sudden commodity price crashes or rallies on producer milk checks. When market prices rally, announced prices are higher than advanced prices, and the PPD will be lower, and vice versa. From Equation [27], the PPD impact from the increase in the announced butterfat price, holding other announced milk component prices and all advanced prices constant, is

$$
\frac{\partial T P P D}{\partial p_{B F}}=-U_{B F, I} \times T_{B F} \times W_{M} .
$$

To quantify the effect of advanced pricing, the Step 4 model uses the actual advanced dairy product and milk component prices, instead of keeping them equal to announced monthly prices.

Although depressed or elevated announced prices may affect PPD for many months, the impact of advanced pricing on PPD is short term. As soon as commodity prices stabilize at a higher, or lower level, the spread between announced and advances prices reverts to reflecting only seasonality in prices.

Step 5: Class I Pricing Reform of 2018. The base class I skim milk price formula from Equation [10], which included the higher of class III or class IV prices presented hedging challenges for class I milk buyers (Newton and Thraen, 2013). In an attempt to address this problem, the Agriculture Improvement Act of 2018 modified the "higher-of" formula to an "average-of" formula given in Equation [9]. To examine the impact of the class I pricing reform on PPDs, compare the effects of the pricing rules:

$$
\begin{aligned}
& p_{S, I, A, 2000-2018}-p_{S, I, A} \\
& =\left[\max \left(p_{I I I, S, A}, p_{I V, S, A}\right)-\min \left(p_{I I I, S, A}, p_{I V, S, A}\right)-1.48\right] / 2 .
\end{aligned}
$$

When the spread between the higher and the lower of the 2 advanced skim milk pricing factors is lower than $\$ 1.48$, then the reformed formula increases the PPD. When the spread is larger than $\$ 1.48$, then the "higherof" formula results in a higher base class I skim milk price, and thus a higher PPD as well. To quantify the effect of class I skim milk pricing reform, the Step 5 model uses the actual formula for base class I skim milk price for all months since May 2019. As in all previous models, Step 5 model also restricts utilization rates to predicted rates based on trend and seasonal factors.

Step 6: Depooling and Structural Changes. As a final effect, the difference between predicted PPD under Step 5 model, and the actual PPD published by market administrators is assigned to depooling and structural changes in utilization rates. This framework does not allow us to separately identify those 2 factors, but based on monthly variation it is reasonable to assume that almost the entire residual is due to depooling.

\section{Policy Analysis}

We use the framework presented above to explore effects of several FMMO reforms on PPD. These potential reforms include (1) changes in class I skim milk price formula, (2) changes in make allowances, and (3) change in the level of standard component tests used for class III and IV skim milk prices.

Changes in Class I Pricing Formula. Due to negative effect of the class I pricing reforms on PPD in 2020, several alternative class I pricing formulas are considered. In this section we explore the consequences of the following 4 class I pricing alternatives on PPD:

- Option A: class I skim milk price is set equal to average of advanced class III skim milk pricing factor and advanced class IV skim milk pricing factor, augmented by $\$ 0.74 /$ cwt.

- Option B: class I skim milk price is set equal to average of advanced class III skim milk pricing factor and advanced class IV skim milk pricing factor, augmented by $\$ 1.00 /$ cwt.

- Option C: class I skim milk price is set equal to average of advanced class III skim milk pricing factor and advanced class IV skim milk pricing factor, augmented by $\$ 1.63 /$ cwt. 
- Option D: class I skim milk price is set equal to advanced class III skim milk pricing factor, augmented by $\$ 0.50 /$ cwt.

\section{RESULTS AND DISCUSSION}

The effects of trends in utilization rates (Step 1 estimated using Equation [31]) by FMMO are presented in Table 4. The estimation period was January 2005 through December 2019. In all federal orders analyzed, class I skim milk utilization rate had a statistically significant negative trend coefficient. Note that California is excluded from this analysis because it joined the federal system at the end of the period analyzed. All data are from USDA Agricultural Marketing Service (2021). Between January 2010 and January 2021, predicted class I skim milk utilization rate declined between 3.4 percentage points (Central FMMO), and 13.7 percentage points (Northeast FMMO). Predicted class I butterfat utilization rate had a statistically significant negative trend coefficient in 5 of the 6 orders with the Central order being the exception. Predicted class I butterfat utilization declined 2.3 to $6.8 \%$ in the other 5 orders. The trend in class III skim utilization was positive in all FMMO except the Central.

To quantify the impact of increases in component tests, the Step 2 model uses the actual component tests rather than component tests observed in 2010. All other restrictions and assumptions are the same as in the Step 1 model. Table 2 compares the average component tests for each order from 2008 to 2009 to the average tests in 2020. In every order and for every component, the values were increased in 2020 compared with the baseline. In both absolute and relative values, butterfat tests increased the greatest amount in each order. Because all milk is first paid for at class III prices for components, these increasing component tests will, ceteris paribus, decrease the PPD.

To quantify the effect of variability in dairy product prices, the Step 3 model uses the actual announced dairy product and milk component prices, instead of being fixed at average prices observed from 2010 to 2019. All other restrictions and assumptions are the same as in the Step 2 model. Table 4 displays the average, range, and measures of variation for the wholesale dairy product prices and resulting component prices from 2010 to 2019. With regard to variability in announced component prices, an example of the effect of the spread between class III and class IV milk prices on predicted PPD for the Mideast federal order is displayed in Figure 1.

Step 4 allows advanced prices to differ from announced prices which captures the effects of dairy product price rallies and crashes on the PPD. Because of the lag between the advanced prices which are used in classes I and II and the announced prices which are used in classes III and IV, the PPD will move opposite these differences. Therefore, a cheese price rally during the period between the advanced and announced prices will result in a lower PPD (and vice versa). The effect of cheese price rallies and crashes on the PPD in the Southwest Order are displayed in Figure 2.

Step 5 considers the impact of the 2019 class I pricing reform - the change from higher of class III and IV price to the average of plus a fixed differential - on the PPD. The effect on the PPD in the Northeast federal order are displayed in Figure 3. When advanced class III and class IV skim milk prices are identical, the PPD in Northeast is approximately $\$ 0.20 /$ cwt higher than would be under the previous class I pricing regimen. Due to extraordinarily large spreads between class III and class IV skim prices during the COVID-19 pandemic, the "average-of" formula resulted in PPDs that were considerably lower than they would have been under the previous price regimen.

Step 6 assigns the remaining difference between the actual and predicted PPD to the depooling and any unaccounted-for structural changes that occurred in the past decade in each order. The effect of depooling varied across orders but was particularly pronounced in those with large class III (cheese) utilization.

\section{Relative Importance of Factors Contributing to PPDs}

Quantifying the relative importance of 6 steps described in the previous section can be approached in 2 ways. We can ask what explains the difference between the baseline and actual PPD levels in a particular month and a particular federal order. Alternatively, we can focus on summary statistics that quantify relative importance of these factors to variation around PPD. We use the Central order PPD for August 2020 as an example to demonstrate how this PPD decomposition approach explains the drivers of PPD. The waterfall chart in Figure 4 illustrates the contribution of each factor to the Central order PPD for August 2020. The baseline PPD for a particular calendar month is defined as the PPD predicted under the Step 1 model for that calendar month. In this case, the baseline PPD is $\$ 0.91 /$ cwt, the predicted PPD for the Central order for August 2010. In contrast, the actual PPD for August 2020 in the Central order was $-\$ 3.62 /$ cwt. To arrive at that $\$ 4.53 /$ cwt difference, consider the factors defined above for the Central order in August 2020.

The predicted utilization rate for class I skim milk was $35.8 \%$ for August 2010, and 31.5\% for August 2020. In August 2010, pool average component tests were $3.44 \%$ 
for butterfat and $2.95 \%$ for protein. In contrast, in August 2020 average tests were $3.73 \%$ for butterfat and $3.09 \%$ for protein. Long-term trends in utilization rates and component tests (Step 2) reduced the predicted
PPD by $\$ 0.42 /$ cwt. From 2010 to 2019 , the average spread between class III and class IV prices was $\$ 0.39$ / cwt. In August 2020, the spread between class III and class IV prices was near the historic high, $\$ 7.24 /$ cwt.

Table 4. Estimated trend and seasonal analysis of utilization rates under different Federal Milk Marketing Orders (FMMO) ${ }^{1}$

\begin{tabular}{|c|c|c|c|c|c|c|}
\hline Utilization rate & Intercept & Trend & $\begin{array}{l}\text { Seasonal } \\
\quad(\sin )\end{array}$ & $\begin{array}{l}\text { Seasonal } \\
(\cos )\end{array}$ & $\begin{array}{c}\text { Jan. } 2010 \\
\text { predicted \% }\end{array}$ & $\begin{array}{c}\text { Jan. } 2021 \\
\text { predicted \% }\end{array}$ \\
\hline \multicolumn{7}{|l|}{ FMMO \#1 - Northeast } \\
\hline Skim milk, class I & $49.06^{*}$ & $-0.10^{*}$ & $-1.30^{*}$ & $2.59^{*}$ & 44.3 & 30.6 \\
\hline Skim milk, class II & $19.06^{*}$ & $0.03^{*}$ & $-0.75^{*}$ & $-1.24^{*}$ & 19.7 & 24.2 \\
\hline Skim milk, class III & $22.44^{*}$ & $0.02 *$ & $-0.60^{*}$ & -0.24 & 23.3 & 26.3 \\
\hline Skim milk, class IV & $9.44^{*}$ & $0.05^{*}$ & $2.65^{*}$ & $-1.11^{*}$ & 12.7 & 19.0 \\
\hline Butterfat, class I & $24.83^{*}$ & $-0.05^{*}$ & $-1.38^{*}$ & $0.99^{*}$ & 22.1 & 15.9 \\
\hline Butterfat, class II & $40.52^{*}$ & $-0.03^{*}$ & $-1.50^{*}$ & $-2.11^{*}$ & 36.4 & 33.0 \\
\hline Butterfat, class III & $23.04^{*}$ & $0.04^{*}$ & -0.27 & 0.05 & 25.7 & 31.6 \\
\hline Butterfat, class IV & $11.61^{*}$ & $0.03^{*}$ & $3.15^{*}$ & $1.06^{*}$ & 15.8 & 19.5 \\
\hline \multicolumn{7}{|c|}{ FMMO \#30 - Upper Midwest } \\
\hline Skim milk, class I & $19.59^{*}$ & $-0.07^{*}$ & 0.15 & 0.78 & 16.3 & 7.5 \\
\hline Skim milk, class II & $4.91 *$ & -0.01 & -0.20 & -0.06 & 4.4 & 3.8 \\
\hline Skim milk, class III & $72.77^{*}$ & $0.07^{*}$ & -0.55 & -0.97 & 75.8 & 84.9 \\
\hline Skim milk, class IV & $2.72^{*}$ & $<0.01$ & $0.60^{*}$ & 0.25 & 3.4 & 3.8 \\
\hline Butterfat, class I & $7.60^{*}$ & $-0.02^{*}$ & -0.07 & 0.17 & 6.2 & 3.0 \\
\hline Butterfat, class II & $11.99^{*}$ & $-0.03^{*}$ & -0.30 & -0.41 & 9.8 & 6.2 \\
\hline Butterfat, class III & $72.33^{*}$ & $0.04^{*}$ & -0.75 & -0.77 & 73.5 & 78.2 \\
\hline Butterfat, class IV & $8.07 *$ & $0.02^{*}$ & $1.12^{*}$ & $1.01^{*}$ & 10.5 & 12.6 \\
\hline \multicolumn{7}{|l|}{ FMMO \#32 - Central } \\
\hline Skim milk, class I & $36.39^{*}$ & $-0.03^{*}$ & $-1.85^{*}$ & $2.69^{*}$ & 36.2 & 32.8 \\
\hline Skim milk, class II & $14.13^{*}$ & $-0.03^{*}$ & $-0.77^{*}$ & $-1.10^{*}$ & 11.2 & 7.9 \\
\hline Skim milk, class III & $37.71^{*}$ & 0.02 & 1.42 & -1.19 & 38.6 & 41.3 \\
\hline Skim milk, class IV & $11.76^{*}$ & $0.03^{*}$ & $1.20^{*}$ & -0.40 & 13.9 & 18.0 \\
\hline Butterfat, class I & $16.58^{*}$ & $<0.01$ & $-1.29^{*}$ & $0.65^{*}$ & 16.3 & 15.7 \\
\hline Butterfat, class II & $25.28^{*}$ & $-0.02^{*}$ & $-1.97^{*}$ & $-1.95^{*}$ & 21.6 & 19.3 \\
\hline Butterfat, class III & $36.88^{*}$ & $0.03^{*}$ & 0.92 & -0.96 & 38.4 & 42.4 \\
\hline Butterfat, class IV & $21.25^{*}$ & -0.01 & $2.34^{*}$ & $2.26^{*}$ & 23.8 & 22.6 \\
\hline \multicolumn{7}{|l|}{ FMMO \#33 - Mideast } \\
\hline Skim milk, class I & $34.25^{*}$ & $-0.06^{*}$ & -0.98 & $1.87^{*}$ & 41.0 & 34.7 \\
\hline Skim milk, class II & $6.64^{*}$ & $<0.01$ & -0.22 & $-0.37^{*}$ & 15.8 & 17.0 \\
\hline Skim milk, class III & $27.31^{*}$ & $0.05^{*}$ & 1.41 & -0.58 & 34.0 & 28.6 \\
\hline Skim milk, class IV & $31.19^{*}$ & 0.02 & 0.11 & -0.76 & 9.2 & 19.8 \\
\hline Butterfat, class I & $16.09^{*}$ & $-0.03^{*}$ & $-1.02^{*}$ & $0.68 *$ & 19.0 & 16.7 \\
\hline Butterfat, class II & $18.07^{*}$ & $-0.01^{*}$ & $-1.12^{*}$ & $-0.78^{*}$ & 26.7 & 32.0 \\
\hline Butterfat, class III & $29.81^{*}$ & 0.03 & 1.00 & -0.87 & 33.4 & 26.0 \\
\hline Butterfat, class IV & $36.03^{*}$ & 0.01 & 1.14 & 0.96 & 20.9 & 25.3 \\
\hline \multicolumn{7}{|c|}{ FMMO \#124 - Pacific Northwest } \\
\hline Skim milk, class I & $34.25^{*}$ & $-0.06^{*}$ & -0.98 & $1.87^{*}$ & 31.7 & 23.9 \\
\hline Skim milk, class II & $6.64^{*}$ & $<0.01$ & -0.22 & $-0.37^{*}$ & 6.1 & 5.9 \\
\hline Skim milk, class III & $27.31 *$ & $0.05^{*}$ & 1.41 & -0.58 & 30.6 & 37.1 \\
\hline Skim milk, class IV & $31.19^{*}$ & 0.02 & 0.11 & -0.76 & 31.6 & 33.7 \\
\hline Butterfat, class I & $16.09^{*}$ & $-0.03^{*}$ & $-1.02^{*}$ & $0.68^{*}$ & 14.6 & 11.3 \\
\hline Butterfat, class II & $18.07^{*}$ & $-0.01^{*}$ & $-1.12^{*}$ & $-0.78^{*}$ & 16.1 & 14.4 \\
\hline Butterfat, class III & $29.81^{*}$ & 0.03 & 1.00 & -0.87 & 31.5 & 35.6 \\
\hline Butterfat, class IV & $36.03^{*}$ & 0.01 & 1.14 & 0.96 & 37.8 & 38.7 \\
\hline \multicolumn{7}{|c|}{ FMMO \#126 - Southwest } \\
\hline Skim milk, class I & $45.18^{*}$ & $-0.06^{*}$ & $-2.47^{*}$ & $2.39^{*}$ & 42.3 & 34.4 \\
\hline Skim milk, class II & $11.54^{*}$ & $-0.02^{*}$ & -0.36 & $-0.81^{*}$ & 9.6 & 7.2 \\
\hline Skim milk, class III & $30.14^{*}$ & $0.06^{*}$ & -0.47 & -0.05 & 33.7 & 42.0 \\
\hline Skim milk, class IV & $13.14^{*}$ & 0.02 & $3.30^{*}$ & -1.54 & 14.4 & 16.4 \\
\hline Butterfat, class I & $27.69^{*}$ & $-0.05^{*}$ & $-1.95^{*}$ & 0.17 & 23.7 & 16.9 \\
\hline Butterfat, class II & $26.45^{*}$ & 0.00 & $-1.81^{*}$ & -1.39 & 24.2 & 23.9 \\
\hline Butterfat, class III & $30.78^{*}$ & $0.07^{*}$ & -0.61 & -0.11 & 34.5 & 43.5 \\
\hline Butterfat, class IV & $15.07^{*}$ & -0.01 & $4.37^{*}$ & 1.33 & 17.5 & 15.7 \\
\hline
\end{tabular}

${ }^{1}$ Data source: USDA-AMS, Federal Milk Marketing Order Statistics, 2010-2020 (https://www.ams.usda.gov/resources/marketing-order -statistics). Estimates using Equation [31]: $U_{t}=\beta_{1}+\beta_{2} N_{t}+\beta_{3} \sin \left(\frac{m_{t}}{12} \times 2 \pi\right)+\beta_{4}\left(\frac{m_{t}}{12} \times 2 \pi\right)+e_{t}$. All other factors constant including component

*Indicates significance at $P<0.05$ 
At the onset of COVID-19 pandemic, both class III and IV prices sharply declined. However, large-scale USDA intervention through cheese purchases, particularly the Farmers to Families Food Box program, elevated class III prices up to $\$ 19.77 /$ cwt in August 2020, while leaving class IV prices at a low of $\$ 12.53 /$ cwt. The resulting spread of $\$ 7.24 /$ cwt was the third-largest spread observed up to that month, exceeded only by spreads in June and July 2020. Taking actual announced monthly prices into consideration (Step 3), the predicted PPD was further reduced by $\$ 2.33 /$ cwt. Weekly surveyed cheese prices dropped from $\$ 2.71 / \mathrm{lb}$ for the week ending on July 18,2020 , to $\$ 1.84 /$ cwt for the week ending on August 29, 2020. Consequently, advanced class III skim milk price for August was $\$ 18.08 /$ cwt, while the announced monthly class III skim price for August was only $\$ 14.58 /$ cwt. Advanced prices for August, published on July 22, before cheese prices dropped, contributed to higher handler obligations to the federal order pool than had the class I skim milk price been set based on monthly announced prices. Accounting for advanced prices (Step 4), increased the predicted PPD by $\$ 1.29$ / cwt. In August 2020, the advanced class IV skim milk price was only $\$ 7.12 /$ cwt. The spread between the advanced class III skim milk price and advanced class IV skim milk price was $\$ 10.96 /$ cwt. The magnitude of this spread was unprecedented, exceeding the average spread between advanced skim milk prices by 5.7 standard deviations. Consequently, the 2019 class I milk pricing reform (Step 5) reduced the predicted PPD by $\$ 1.44 /$ cwt, pushing it down to $-\$ 1.99 /$ cwt .

The resulting actual observed PPD at $-\$ 3.62 / \mathrm{cwt}$ was considerably more negative than predicted by model in the Step 5 (Figure 4). Three years earlier, in August 2017, when PPD was positive, class III receipts of milk and cream totaled $693,753,584$ lbs. In contrast, class

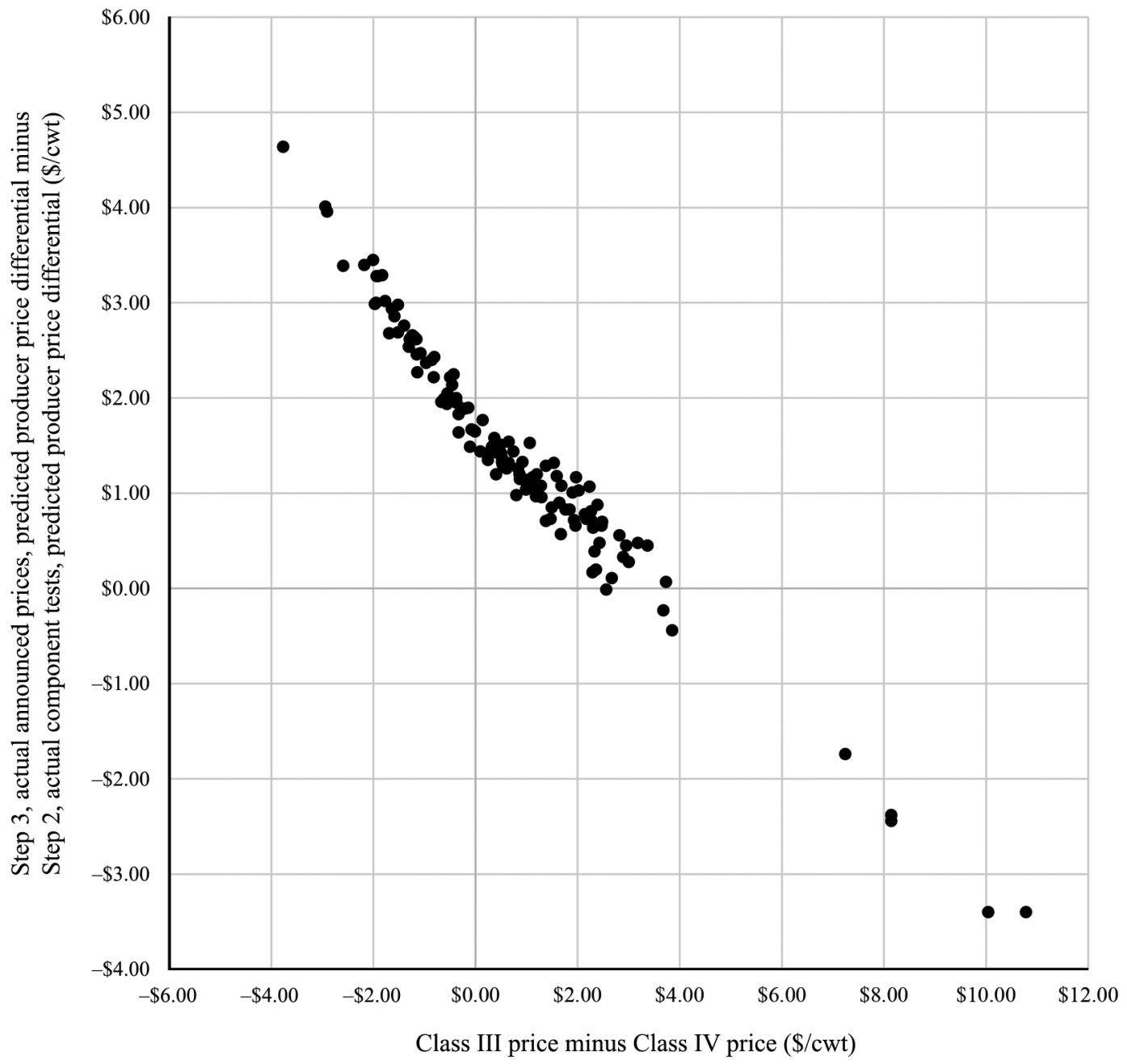

Figure 1. Impact of variability in announced prices on predicted producer price differentials (PPD) in Federal Milk Marketing Order \#33 - Mideast. cwt $=$ hundredweight. 


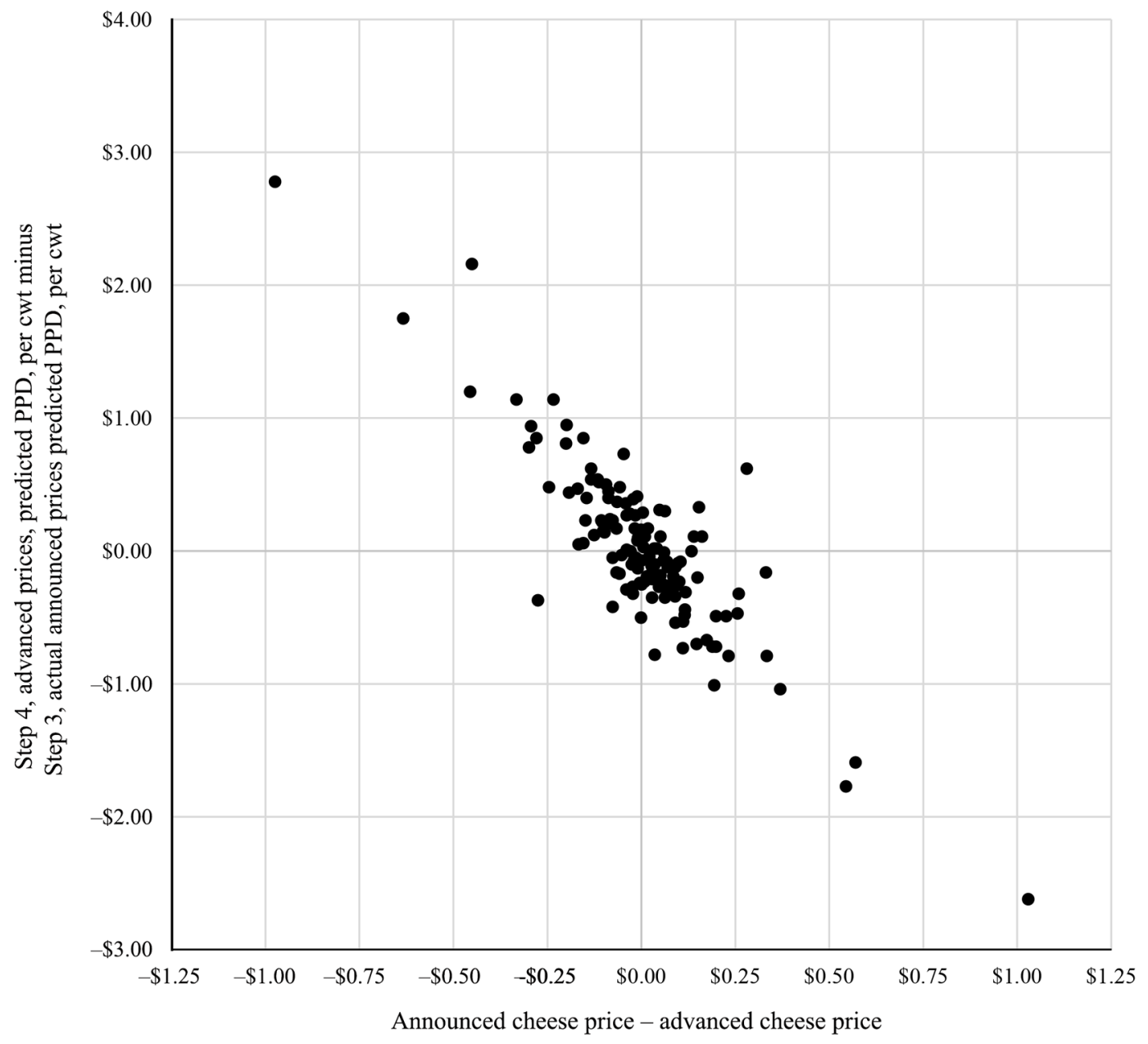

Figure 2. Impact of cheese price rallies and crashes on predicted producer price differentials (PPD) in Federal Milk Marketing Order \#126 - Southwest. cwt $=$ hundredweight.

III receipts were only 27,017,766 lbs in August 2020 a decline of $96 \%$. The result was that class III skim milk utilization rate dropped to only $2.91 \%$, in August 2020 down from $47.4 \%$ in August 2017. Over this period, there was no news of substantial dairy plant closures or openings, and USDA estimates that cheese production increased in August 2020 compared with prior years. As such, we conclude that the change in utilization rates is not due to sudden structural changes in utilization rates, but the decision of class III handlers to opt out of the pool for August 2020. Depooling reduced the PPD by $\$ 1.63 /$ cwt relative to what would have been the case had the utilization rates remained at their historical trend and seasonal levels.

Following this decomposition of factors, Table 5 presents annual average effects on PPD in 2020 for all analyzed federal orders. All 6 orders went from a positive baseline to a negative PPD value on average in 2020, the spread between class III and IV milk prices (captured by Step 3) contributed $-\$ 1.73 /$ cwt to PPD. Class I reform reduced PPD by $\$ 0.46 /$ cwt (captured by Step 5), whereas depooling and structural changes removed $\$ 0.77 /$ cwt (Step 6). The largest decline in PPD in relative value from changing utilization rates was in the Pacific Northwest $(-\$ 0.25 /$ cwt relative to a $\$ 0.52 /$ cwt baseline estimate) order, whereas the largest decline due to utilization in absolute value occurred in the Northeast order $(-\$ 0.43 / \mathrm{cwt})$. The Southwest order realized the largest decline in PPD due to increased component tests $(-\$ 0.29 /$ cwt $)$. The large magnitude of the spread between class III and class IV prices was responsible for the largest portion of the decline in PPD relative to the baseline in 5 of the 6 orders. The exception was the Upper Midwest where the largest effect was depooling.

Because each of analyzed factors can have either positive or negative effect on PPD in a particular month, their relative importance over longer time intervals is 


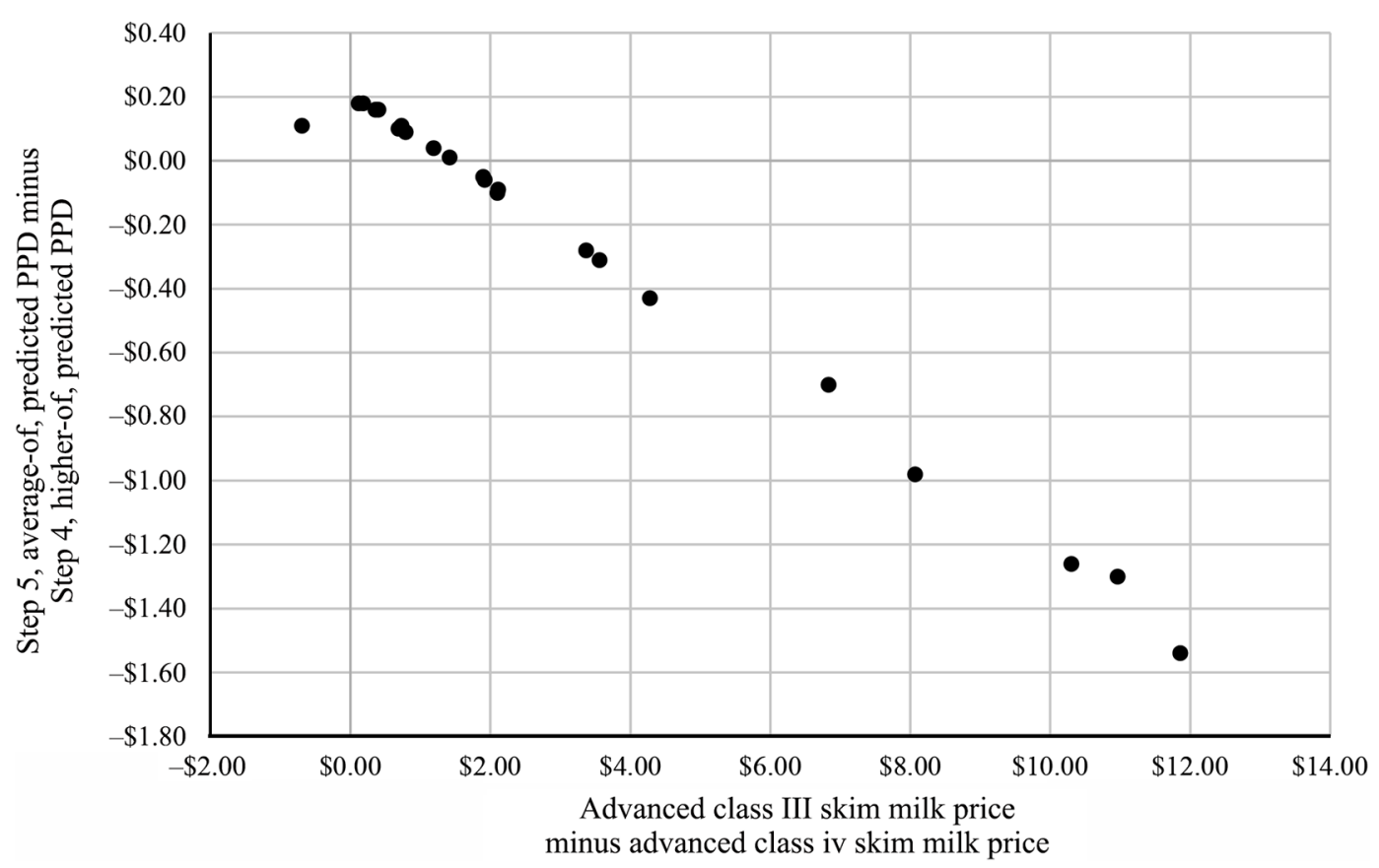

Figure 3. Impact of class I pricing policy reform on producer price differentials (PPD) in Federal Milk Marketing Order \#1 - Northeast, May 2019-Feb 2021. cwt $=$ hundredweight.

better measured through impact on variability of actual PPD around base values. To that end we calculate the sum of squared differences between actual and baseline PPD. We then calculate the sum of squared predic- tion errors under each model and calculate the ratio of the reduction in the sum of squared errors across consecutive steps to the sum of squared prediction errors against baseline values.

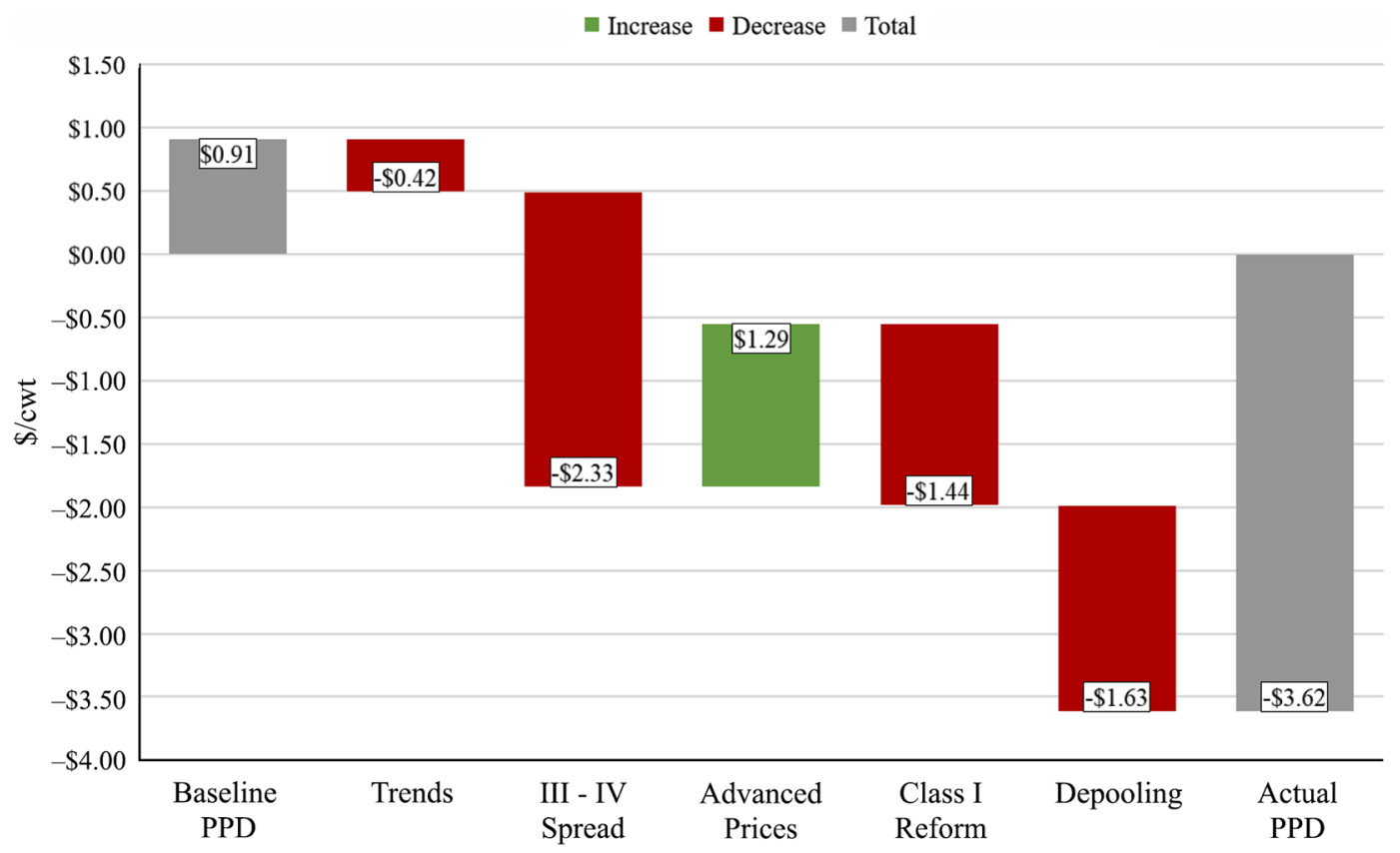

Figure 4. Contributions to producer price differential (PPD) in Federal Milk Marketing Order \#32 - Central for August 2020. cwt $=$ hundredweight. 
For example, in the Pacific Northwest federal order, the sum of squared differences between actual and baseline PPD over January 2010 through February 2021 is equal to 337.33 . The sum of squared prediction errors for Step 2 component tests is 299.55. And the sum of squared prediction errors for Step 3 actual announced prices is 30.22 . Thus, the percent of variation explained by variability in announced monthly prices is calculated as $(299.55-30.22) / 337.33$, which is equal to $79.8 \%$. Figure 5 displays the relative magnitude of average variation around the baseline PPD values over the period from January 2010 through February 2021, as well as the contribution of each factor to the variation. The Upper Midwest PPD squared difference was smaller than the other orders' differences. The largest percent of variation was explained by the wide spread between class III and class IV prices that occurred during 2020. Depooling was a large effect in the Upper Midwest, Central and Southwest orders.

\section{Policy Aspects}

Changes in Make Allowances. As demonstrated in the previous section, the largest contributor to negative PPD in 2020 was the spread between class III and class IV milk prices. The proximate causes were government purchases made for the Farmers to Families Food Box program implemented by USDA to counter COVID-19 effects on food security and faltering dairy markets, and depressed butter prices due to reduced foodservice demand. However, a deeper question is why US dairy sector did not have more flexibility to shift production toward cheese types that could be sold in retail or distributed through donation boxes. One reason may be that the cheese and whey make allowances, not updated since 2010, no longer accurately reflect true cheese manufacturing costs. The current cheese make allowance is $\$ 0.2003 / \mathrm{cwt}$, the dry whey make allowance is $\$ 0.1991 /$ cwt, the butter make allowance is $\$ 0.1715 /$ cwt and the nonfat dry milk make allowance is $\$ 0.1678 /$ cwt. Examining the impact of changes in make allowance on commodity prices is beyond the scope of this article. We can, however, examine the effect on milk component prices, given historical commodity prices. For illustration, we modified the cheese make allowance to $\$ 0.235 / \mathrm{cwt}$, the butter make allowance to $\$ 0.18 /$ cwt, the dry whey make allowance to $\$ 0.205 /$ cwt, and the nonfat dry milk make allowance to $\$ 0.18$ / cwt. The effects of modified make allowances are illustrated in Table 6.

Changes in Standard Milk Component Tests. Class III and class IV milk prices use standard component tests: 3.5 pounds of butterfat per hundredweight of milk, and 3.1 pounds of protein and 5.9 of other

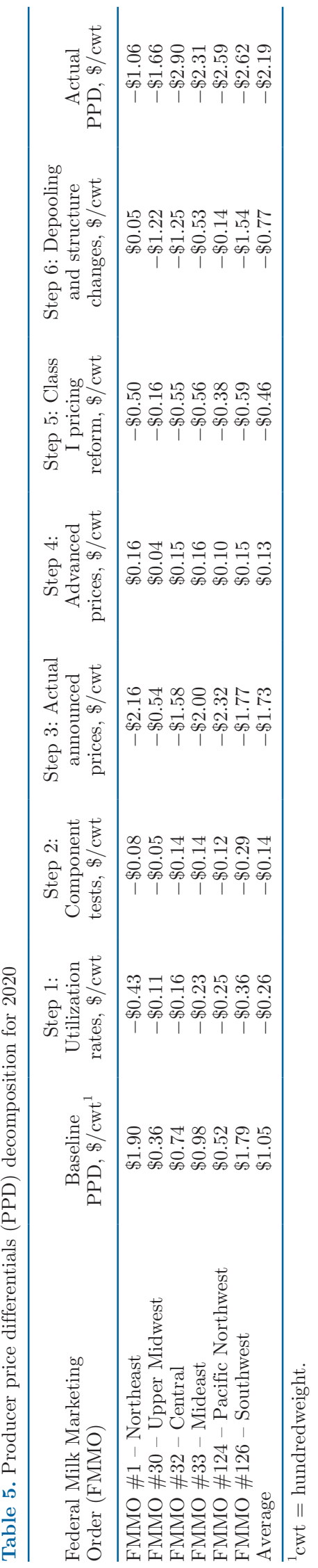


solids per hundredweight of skim milk. These component tests reflect the average milk solids tests in late 1990s, before the last major federal order reform which occurred in 2000 (Bailey and Tozer, 2001). However, as demonstrated previously, average component tests have since increased considerably. Class I handler obligations to the pool are based on skim milk definition with 3.1 pounds of protein, although such milk may have much higher protein content. This misalignment contributes to negative trends in PPD over time. In this experiment we modify standard class tests to be 4.0 pounds of butterfat per hundredweight of milk and 3.4 pounds of protein per hundredweight of skim milk. We keep the other solids test at current level (5.9 pounds).

The effects of these changes on 2015 to 2020 average PPD are presented in Table 6. Reviewing the class I pricing proposals, we find that had the average-of pricing regimen with $\$ 1.00 /$ cwt adjustor been in effect from 2015 , the average PPD under the $\$ 1.00 /$ cwt adjustor would have been nearly the same as under the higher-of regimen. Proposals with $\$ 1.63 /$ cwt adjustor, or based solely on advanced class III skim milk pricing factors would have resulted in higher PPD and lower frequency of negative PPD. Similarly, adjusting make allowances increases average PPD by $\$ 0.04 /$ cwt in Upper Midwest, up to $\$ 0.16 /$ cwt in Northwest. Increasing butterfat and protein tests in standard class III and class IV prices has a material impact on PPD, with average increase in the Northeast and Southwest orders near to $\$ 0.20 /$ cwt. Similarly, the frequency of negative PPD was reduced under the alternative pricing proposals but would still be a regular occurrence in many FMMO.

A phrase often used to describe the primary goal of FMMO regulations is "orderly marketing," which is taken to mean well behaved milk distribution, dependable and equitable contractual relationships between beverage milk handlers and milk producers, and reliable relationships for prices and supplies between different markets (Manchester, 1983). Orderly marketing must also include incentives to direct milk to dairy products where the milk adds the most value. That in turn means incentives for production capacity utilization to be low

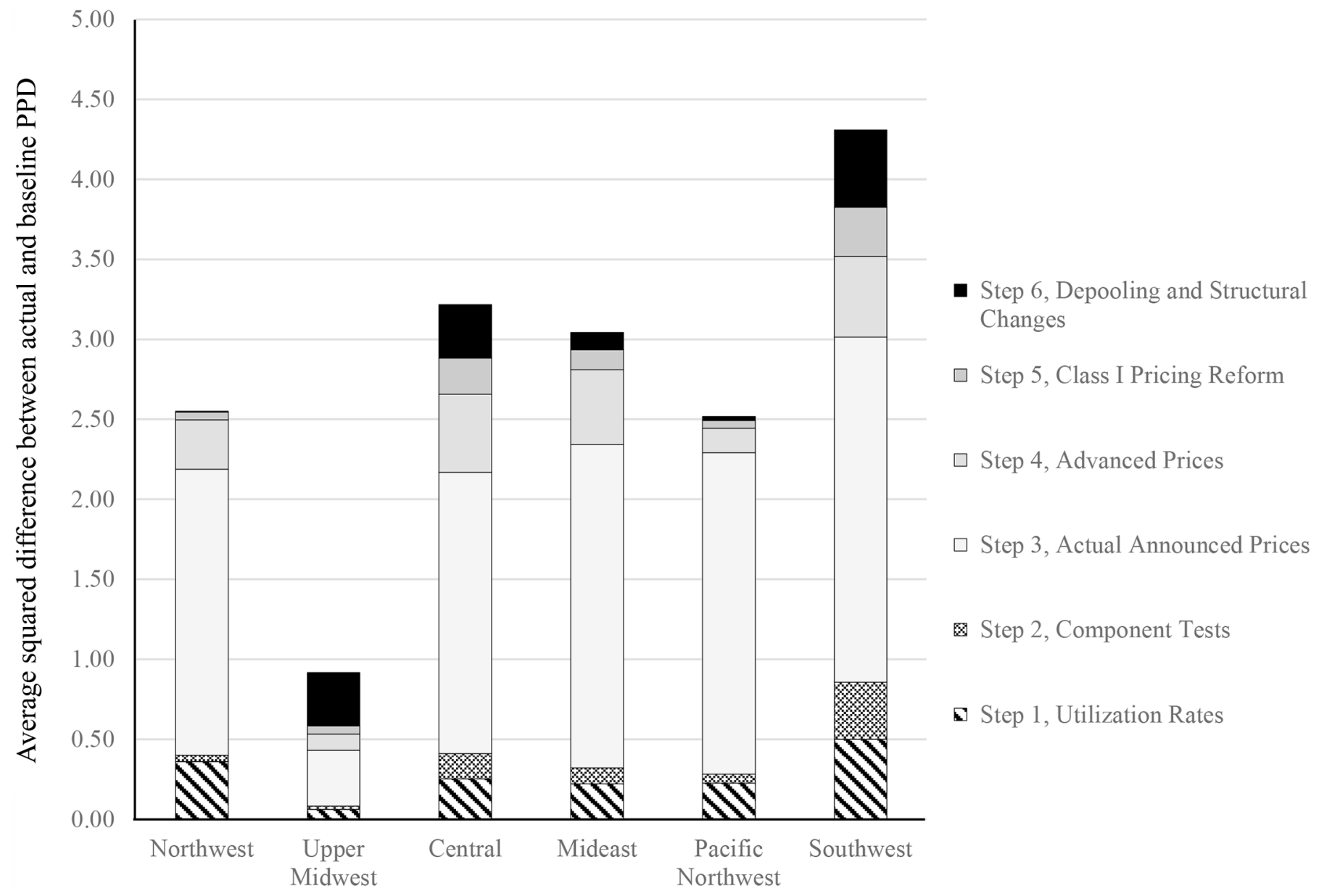

Figure 5. Relative importance of factors to variation around baseline producer price differentials (PPD), 2010-2021. 


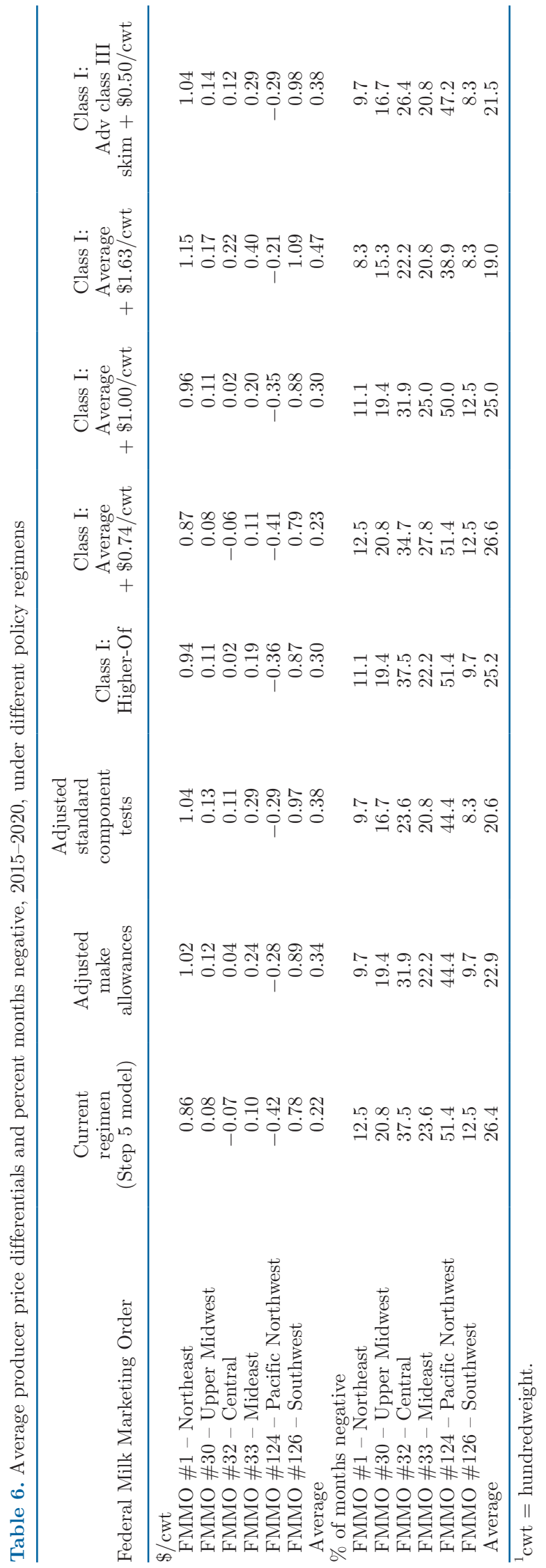

enough to allow flexibility in dairy product production in response to changes in demand. One step toward that realignment might be to adjust make allowances to accurately reflect dairy processing costs. Our models show that adjusting make allowances can reduce the spread between the value of skim solids in cheese and dry milk products, and thus increase PPD both directly, and indirectly through incentives to augment aggregate cheese making capacity. The "average-of" approach results in a higher PPD when the value of skim solids is sufficiently similar in cheese and milk powder markets, and thus should perform more advantageously to dairy producers if the underlying drivers of wide spreads between class III and class IV milk prices are properly addressed.

Beyond adjusting make allowances, research should explore how product formulas may be altered to provide additional incentives to manufacturers to quickly adjust product mix in response to demand shocks. Finally, a key limitation of our models is that we cannot ascribe how much of the depooling is due to each underlying factor, which is why all our models assume trend-seasonal utilization rates. Future research might focus on developing optimal depooling models. Further, on the issue of depooling, it is important to note that, historically, equalization in producer prices was driven by large revenue transfers from beverage milk class to manufactured milk classes. With waning of fluid milk sales and growth in domestic and export demand for manufactured products, in most market orders class I revenue is no longer sufficient to provide even shortterm equalization of mailbox prices for producers whose milk is used in powder versus cheese production. Future research might consider market order formulations which avoid persistent problems with depooling and negative and increasingly volatile PPD happening ever more frequently under the current system. It is almost certain that such reform will need to be more comprehensive than simply adjusting make allowances or the class I milk pricing formula.

\section{CONCLUSIONS}

We developed a framework to quantify relative contributions of 6 aspects of milk pricing under FMMO on PPDs: (1) long-term trends in utilization of milk in beverage compared with manufactured dairy products, (2) seasonal and long-term trends in butterfat and protein content of milk, (3) variability in dairy product prices, (4) advanced pricing used for beverage milk products, (5) class I milk pricing reform enacted in the 2018 Farm Bill, and (6) voluntary removal of milk used for manufacturing from market orders (i.e., depooling). We found that long-term trends in utiliza- 
tion and component tests substantially reduced PPD over the past decade. There is no reason to think these trends will reverse course at the current time. Class I milk pricing reform of 2018 exacerbated negative PPD in 2020, but our analysis suggests the PPD would likely have been negative in many instances regardless of this change. The greatest contributor to recent negative PPD was the spread between cheese and milk powder prices, which were further aggravated by ad hoc government intervention programs introduced to counter the impact of the COVID-19 pandemic on food security and commodity markets. Finally, depooling was a large contributor to negative PPD, particularly in the Upper Midwest, Central, and Southwest Orders.

\section{ACKNOWLEDGMENTS}

This study received no external funding. The authors thank 2 anonymous reviewers and the editor for their assistance. The authors have not stated any conflicts of interest.

\section{REFERENCES}

Bailey, K. W., C. M. Jones, and A. J. Heinrichs. 2005. Economic returns to Holstein and Jersey herds under multiple component pricing. J. Dairy Sci. 88:2269-2280. https://doi.org/10.3168/jds .S0022-0302(05)72903-9.

Bailey, K., and P. Tozer. 2001. An evaluation of federal order reform. J. Dairy Sci. 84:974-986. https://doi.org/10.3168/jds.S0022 -0302(01)74556-0.

Bozic, M., J. Newton, C. S. Thraen, and B. W. Gould. 2012. Meanreversion in income over feed cost margins: Evidence and implications for managing margin risk by US dairy producers. J. Dairy Sci. 95:7417-7428. https://doi.org/10.3168/jds.2012-5818.

Congressional Research Service. 2017. Federal Milk Marketing Orders: An Overview. CRS Report R45044. Congressional Research Service.

De Vries, A., and S. Feleke. 2008. Prediction of future uniform milk prices in Florida federal milk marketing order 6 from milk futures markets. J. Dairy Sci. 91:4871-4880. https://doi.org/10.3168/jds .2008-1138.

Jesse, E. V., and R. A. Cropp. 2008. Basic Milk Pricing Concepts for Dairy Farmers. Cooperative Extension, University of WisconsinExtension, Bulletin A3379 University of Wisconsin Extension.

Manchester, A. C. 1983. The Public Role in the Dairy Economy: Why and How Governments Intervene in the Milk Business. Westview Press.

Newton, J., and C. S. Thraen. 2013. Road block to risk management - Investigating class I Milk cross-hedging opportunities. Appl. Econ. Perspect. Policy 35:550-564. https://doi.org/10.1093/aepp/ ppt017.

Nourse, E. G. 1962. What lies ahead for Federal Milk Marketing Orders: Objectives and means. J. Dairy Sci. 45:1405-1408. https:// doi.org/10.3168/jds.S0022-0302(62)89638-6.

Paggi, M., and C. F. Nicholson. 2013. Federal and State Marketing Orders. Pages 137-169 in US Programs Affecting Food and Agricultural Marketing (Natural Resource Management and Policy). W. J. Armbruster and R. D. Knutson, ed. Springer.

Stephenson, M., and A. M. Novakovic. 2020. Making Sense of Your Milk Price in the Pandemic Economy: Negative PPDs, Depooling and Reblending. Dairy Markets and Policy Information Letter 20-03. Dairy Markets and Policy. https://dairymarkets.org/ PubPod/Pubs/IL20-03.pdf

Swantz, A. 1962. How we came to have Federal Milk Marketing Orders: What they are and what they do. J. Dairy Sci. 45:1397-1402. https://doi.org/10.3168/jds.S0022-0302(62)89635-0.

USDA. 2020. USDA Farmers to Families Food Box. USDA, Agricultural Marketing Service. Accessed Apr. 25, 2021. https://www.ams .usda.gov/selling-food-to-usda/farmers-to-families-food-box.

USDA Agricultural Marketing Service. 2019. Marketing Order Statistics Price Formulas 2019. USDA. Accessed Apr. 25, 2021. https:// www.ams.usda.gov/resources/price-formulas.

USDA Agricultural Marketing Service. 2020. Measures of Growth in Federal Orders. USDA. Accessed Apr. 25, 2021. https://www.ams .usda.gov/sites/default/files/media/MeasuresofGrowth19472019 .pdf.

USDA Agricultural Marketing Service. 2021. Milk marketing order statistics. USDA. Accessed Apr. 24, 2021. https://www.ams.usda .gov/resources/marketing-order-statistics.

Wolf, C. A. 2012. Dairy farm use of price risk management tools. J. Dairy Sci. 95:4176-4183. https://doi.org/10.3168/jds.2011-5219.

\section{ORCIDS}

Marin Bozic @ https://orcid.org/0000-0002-3010-9037

Christopher A. Wolf $\odot$ https://orcid.org/0000-0003-4181-285X 